\title{
Growth of Long Pepper (Piper rectofractum Vahl.) with Different Growing Media Composition
}

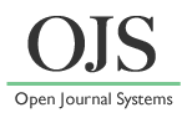

\author{
Wuri Prameswari $^{1 *}$, Welly Herman ${ }^{2}$, Umi Salamah $^{1}$ \\ ${ }^{1}$ Agroecotechnoloy Study Program, Faculty of Agriulture, University of Bengkulu \\ ${ }^{2}$ Soil Science Study Program, Faculty of Agriculture, University of Bengkulu \\ *Email: wprameswari@unib.ac.id
}

DOI: https://doi.org/10.33369/pendipa.5.3.345-350

\begin{abstract}
Long pepper (Piper retrofractum Vahl.) is one of the potential medicinal plants in Indonesia. However, information related to the cultivation of this plant is scarce. Therefore, more research is necessary to determine the suitable planting media for the growth of long pepper. This experiment used a complete randomized group design with one treatment factor for the composition of the growing media, namely soil, soil + sand $(3: 1, v / v)$, soil + rice husk charcoal $(3: 1, v / v)$, and soil + manure $(3: 1, v / v)$. Each treatment repeats six times, and each consisted of 10 plants. Data processing was done using an analysis of variance. The plant material used was in soil tendrils and polybags measuring $30 \mathrm{~cm} \times 30 \mathrm{~cm}$ as a container. $N P K+M g$ inorganic fertilizer with an equivalent dose of 12: 12: 17: 2. The results of the experiment showed that the composition of the different growing media affected all observed variables. The use of soil planting medium + cow manure showed the best growth results of long pepper for plant height, the number of leaves, root length, root and canopy wet weight, and root and canopy dry weight.
\end{abstract}

Keywords: Piperaceae; rice husk; manure; medical plant; polybag.

\begin{abstract}
ABSTRAK
Cabe jamu (Piper retrfractum Vahl.) merupakan salah satu tanaman obat potensial di Indonesia, akan tetapi informasi terkait budidaya tanaman ini masih sangat terbatas. Oleh karena itu diperlukan penelitian terkait penentuan media tanam yang sesuai untuk pertumbuhan tanaman cabe jamu. Percobaan ini menggunaka rancangan kelompok lengkap teracak (RKLT) dengan satu faktor perlakuan komposisi media tanam yaitu tanah, tanah+pasir $(3: 1, \mathrm{v} / \mathrm{v})$, tanah+arang sekam padi $(3: 1, \mathrm{v} / \mathrm{v})$, dan tanah+pupuk kandang sapi $(3: 1, \mathrm{v} / \mathrm{v})$. Setiap perlakuan diulang 6 kali dan masing-masing terdiri atas 10 tanaman. Analisis data menggunakan sidik ragam. Bahan tanaman yang digunakan berupa stek sulur tanah dan polybag berukuran $30 \mathrm{~cm} \times 30 \mathrm{~cm}$ sebagai wadah. Pupuk anorganik NPK+Mg dengan dosis setara 12:12:17:2. Hasil percobaan menunjukkan bahwa komposisi media tanam yang berbeda mempengaruhi semua variabel yang diamati. Penggunaan media tanam tanah+pupuk kandang sapi menunjukkan hasil pertumbuhan cabe jamu terbaik untuk variabel tinggi tanaman, jumlah daun, panjang akar, bobot basah akar dan tajuk serta bobot kering akar dan tajuk.
\end{abstract}

Kata kunci: Piperaceae; arang sekam padi; pupuk kandang sapi; tanaman obat; polybag.

\section{INTRODUCTION}

Piper retrofractum Vahl. or often known as chilli herbs (long pepper), included in the Piperaceae family (Vasavirama and Upender, 2014) which is used as a cooking ingredient (Kartasapoetra, 2004), natural insecticides (Hasnah and Rusdy, 2015; Umami and Purwani, 2015), oral inflammation medicine, bronchitis (Evizal , 2013; Kemal et al., 2013), stomach cramps, asthma (Jamal et al., 2013), influenza (Chaveerach et al., 2006), cholesterol-lowering (Kim et al., 2011), the mother is giving birth (Vinay et al., 2012), as well as antioxidants and anticancer (Subramaniam et al., 2003; Mulia, 2015).

Chilli jamu is an upright terrestrial plant similar to a pepper plant with branches reaching up to $0.5 \mathrm{~m}$. Besides, this plant is a vine planted 
in polybags by cutting branches or vines (Mathew et al., 2004), which can be used as a home medicinal plant and ornamental plant (Melati and Saleh, 2012). Herbal chillies (long pepper) can adapt well to sandy loam soils with loose soil structures and good drainage (Evizal, 2013), with average rainfall ranging from 1250 to $2500 \mathrm{~mm}$ per year (Sulkani, 2013). Besides, herbal chillies also have high adaptability to soils with $\mathrm{pH}$ ranges between 4-8, rocky and less fertile soils (Nurkhasanah et al., 2013).

The chemical compounds contained in chilli herbs consist of saponins, polyphenols, kavisin, alkaloids, palmitic acid, 1-undesilenyl-3-4methylendioxybenzene, sesamin, isobutildekatrans-2-trans-4-dienamide, tetrahydropiperic acid (Supervisory Agency Medicine and Food, 2013), piperin (Ruhnayat et al., 2011; Vinay et al. 2012), and essential oils (Jamal et al., 2013).

Research related to herbal chillies' chemical content had been widely studied; however, information on this plant's cultivation is still minimal. Further studies need to be carried out, especially concerning the composition of the suitable planting medium for medicinal herbs' growth. To study the suitable planting media for chilli herbs, the composition of the planting medium was used, such as soil, soil + sand (3: 1 $\mathrm{v} / \mathrm{v})$, soil + manure $(3: 1 \mathrm{v} / \mathrm{v})$, and soil rice hull (3: $1 \mathrm{v} / \mathrm{v}$ ) in Piper sarmentosum (Melati and Fetiandreny, 2013).

This study aimed to determine the effect of different growing media's composition on the growth of chilli herbs (Piper retrofractum Vahl.).

\section{RESEARCH METHODS \\ Time and Location of Research}

The research was carried out at the Experimental Garden, Faculty of Agriculture, Bengkulu University. This research was conduct from September 2019 to February 2020.

\section{Research Materials}

Soil cuttings use as plant material. Polybag is used as a container for planting media. Organic and inorganic fertilizers and auxins (ZPT) are used as a source of nutrition.

\section{Research design}

The experiment used a completely randomized block design (RKLT) with a single factor (namely the composition of the growing medium) and six replications. The treatments were: soil alone, soil + sand (3: 1, $\mathrm{v} / \mathrm{v})$, soil + rice husk charcoal $(3: 1, \mathrm{v} / \mathrm{v})$, and soil + cow manure (3: 1, v / v ). Each treatment consisted of 10 plants. The total experimental unit is 60 experimental units.

The observational data were analyzed using the $\mathrm{F}$ test. If the treatment showed a significant effect at the $5 \%$ level, the analysis was continued with DMRT (Duncan Multiple Range Test) at the level $\alpha=5 \%$.

\section{Research Stages}

Pre-planting: The base of the plant-soil tendril cuttings dipped in fungicide and bactericide for 30 seconds, then dried, and then re-dipped in root and shoot stimulating hormone 1 minute.

Planting: Planting cuttings that have prepared transferred to polybags measuring $30 \mathrm{~cm} \times 30 \mathrm{~cm}$, filled with the planting medium according to the treatment. After two weeks after planting, NPK $+\mathrm{Mg}$ inorganic fertilizers were added with the recommended dose, namely 12: 12: 17: 2 (Santosa, 1993).

\section{Observation Variable}

The variables observed were plant height, the number of leaves, root length, root and shoot wet weight, and root and shoot dry weight.

\section{RESULTS AND DISCUSSION}

The results show that all observed variables were significantly influenced by the composition of different growing media. The addition of manure to the growing media showed the best growth and production of plant biomass compared to those grown on the other three growing media (Tables 1 and 2). 
Table 1. The growth of plant height, number of leaves, and root length of Piper retrofractum Vahl. with different growing media

\begin{tabular}{|c|c|c|c|c|}
\hline \multirow[b]{2}{*}{ Variable } & \multicolumn{4}{|c|}{ Growing Media Composition } \\
\hline & Soil & $\begin{array}{c}\text { Soil + Sand } \\
(3: 1 / v: v)\end{array}$ & $\begin{array}{c}\text { Soil+Rice Husk } \\
\text { (3:1/v:v) }\end{array}$ & $\begin{array}{c}\text { Soil+Manure } \\
(3: 1 / v: v)\end{array}$ \\
\hline \multicolumn{5}{|c|}{ Plant height $(\mathrm{cm})$} \\
\hline $4 \mathrm{WAP}$ & $7,13 \mathrm{~d}$ & $7,76 \mathrm{c}$ & $8,70 \mathrm{~b}$ & $9,73 \mathrm{a}$ \\
\hline $6 \mathrm{WAP}$ & $9,50 \mathrm{~d}$ & $10,19 \mathrm{c}$ & $12,35 \mathrm{~b}$ & $13,48 \mathrm{a}$ \\
\hline $8 \mathrm{WAP}$ & $11,37 \mathrm{~d}$ & $12,73 \mathrm{c}$ & $16,65 \mathrm{~b}$ & $17,59 \mathrm{a}$ \\
\hline $10 \mathrm{WAP}$ & $14,35 \mathrm{~d}$ & $16,10 \mathrm{c}$ & $21,77 \mathrm{~b}$ & $23,32 \mathrm{a}$ \\
\hline 12 WAP & $17,43 \mathrm{~d}$ & $20,11 \mathrm{c}$ & $28,09 \mathrm{~b}$ & $31,00 \mathrm{a}$ \\
\hline 14 WAP & $20,73 \mathrm{~d}$ & $23,87 \mathrm{c}$ & $36,20 \mathrm{~b}$ & $40,62 \mathrm{a}$ \\
\hline \multicolumn{5}{|l|}{ Leaf numbers } \\
\hline $4 \mathrm{WAP}$ & $2,45 \mathrm{~b}$ & $2,53 \mathrm{ab}$ & $2,78 \mathrm{ab}$ & $2,87 \mathrm{a}$ \\
\hline $6 \mathrm{WAP}$ & $4,37 \mathrm{c}$ & $4,53 \mathrm{bc}$ & $5,07 \mathrm{~b}$ & $5,93 \mathrm{a}$ \\
\hline $8 \mathrm{WAP}$ & $9,25 \mathrm{~b}$ & $10,17 \mathrm{c}$ & $14,02 \mathrm{a}$ & $14,88 \mathrm{a}$ \\
\hline $10 \mathrm{WAP}$ & $15,58 \mathrm{c}$ & $16,67 \mathrm{c}$ & $22,00 \mathrm{~b}$ & $24,50 \mathrm{a}$ \\
\hline 12 WAP & $26,83 \mathrm{~d}$ & $29,33 \mathrm{c}$ & $35,33 \mathrm{~b}$ & $37,40 \mathrm{a}$ \\
\hline 14 WAP & $38,08 \mathrm{~d}$ & $43,67 \mathrm{c}$ & $52,00 \mathrm{~b}$ & 55,83 a \\
\hline \multicolumn{5}{|c|}{ Root length $(\mathrm{cm})$} \\
\hline 14 WAP & $12,86 \mathrm{~d}$ & $15,98 \mathrm{c}$ & $20,16 \mathrm{~b}$ & $21,75 \mathrm{a}$ \\
\hline
\end{tabular}

Table 2. Shoot and root production of Piper retrofractum Vahl. with different growing media

\begin{tabular}{|c|c|c|c|c|}
\hline \multirow[b]{2}{*}{ Variable } & \multicolumn{4}{|c|}{ Growing Media Composition } \\
\hline & Soil & $\begin{array}{c}\text { Soil + Sand } \\
(3: 1 / v: v)\end{array}$ & $\begin{array}{c}\text { Soil+Rice Husk } \\
(3: 1 / v: v)\end{array}$ & $\begin{array}{c}\text { Soil+Manure } \\
(3: 1 / v: v)\end{array}$ \\
\hline Shoot & $13,18 \mathrm{~d}$ & $14,74 \mathrm{c}$ & $17,02 \mathrm{~b}$ & $21,81 \mathrm{a}$ \\
\hline Root & $9,98 \mathrm{c}$ & $9,60 \mathrm{c}$ & $11,58 \mathrm{~b}$ & $15,13 \mathrm{a}$ \\
\hline \multicolumn{5}{|c|}{ 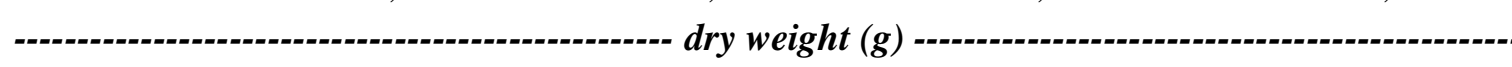 } \\
\hline Shoot & $2,91 \mathrm{~b}$ & $3,11 \mathrm{ab}$ & $3,06 \mathrm{ab}$ & $3,44 \mathrm{a}$ \\
\hline Root & $2,74 \mathrm{ab}$ & $2,22 \mathrm{c}$ & $2,54 \mathrm{~b}$ & $2,85 \mathrm{a}$ \\
\hline \multicolumn{5}{|c|}{ 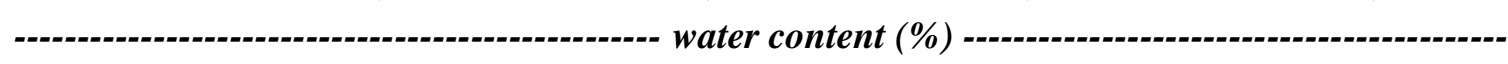 } \\
\hline Shoot & $76,65 \mathrm{~d}$ & $78,87 \mathrm{c}$ & $82,01 \mathrm{~b}$ & 84,26 a \\
\hline Root & $72,28 \mathrm{c}$ & $76,86 \mathrm{~b}$ & $78,08 \mathrm{~b}$ & $81,15 \mathrm{a}$ \\
\hline
\end{tabular}


Table 3. Chemical analysis of growing media

\begin{tabular}{|c|c|c|c|c|c|}
\hline \multirow[b]{2}{*}{ Growing Media Types } & \multicolumn{5}{|c|}{ Variable Analysis } \\
\hline & $\mathbf{p H}$ & $\begin{array}{c}\text { C-Organik } \\
(\%)\end{array}$ & $\begin{array}{c}\text { N- } \\
\text { Total } \\
(\%)\end{array}$ & $\begin{array}{c}\text { P-Bray-I } \\
\text { (ppm) }\end{array}$ & $\underset{(\mathrm{cmol}(+) / \mathrm{kg})}{\mathrm{K}}$ \\
\hline Soil & 4,95 & 2,27 & 0,29 & 1,1 & 0,54 \\
\hline Soil + Sand & 4,95 & 1,02 & 0,13 & 2,35 & 0,3 \\
\hline Soil + rise husk & 5,23 & 1,27 & 0,18 & 5,48 & 0,67 \\
\hline Soil + manure & 6,78 & 6,66 & 0,98 & 116,28 & 10,72 \\
\hline
\end{tabular}

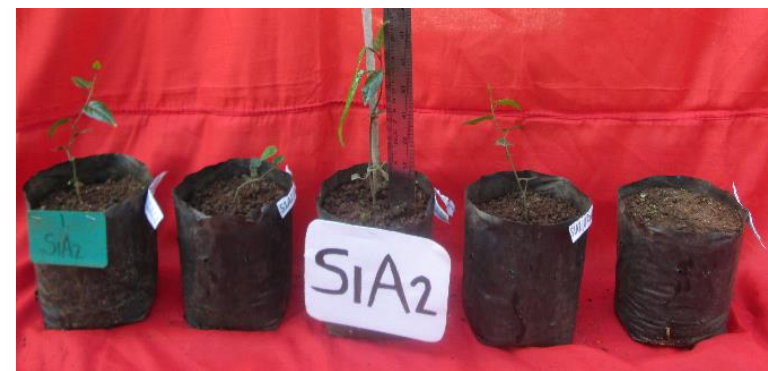

A

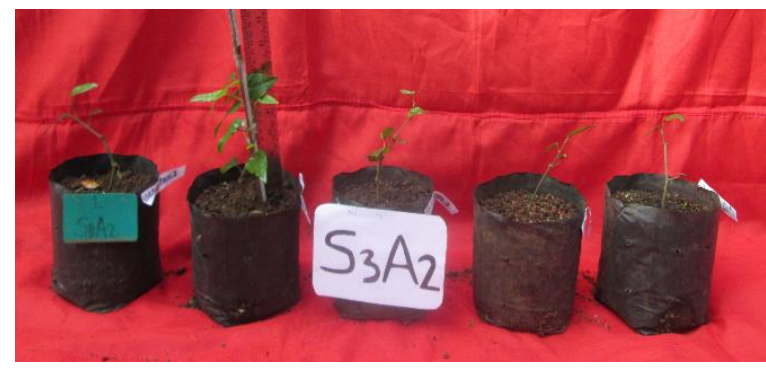

C

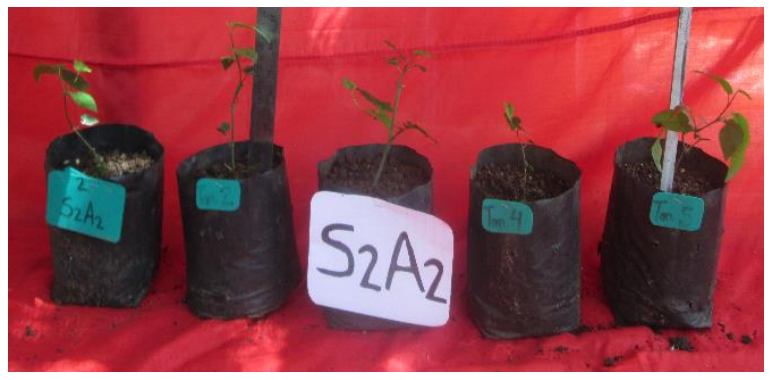

B

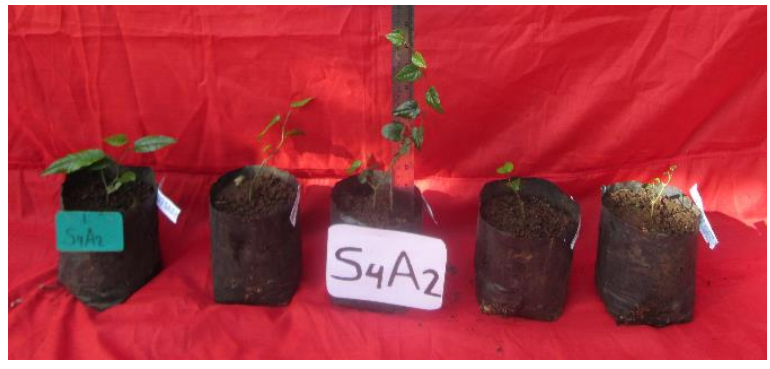

D

Figure 1. Long pepper plant performance three weeks after planting (WAP). $A=$ Soil, $B=$ Soil + Sand,$C=$ Soil+Rice husk, and D = Soil+Manure.

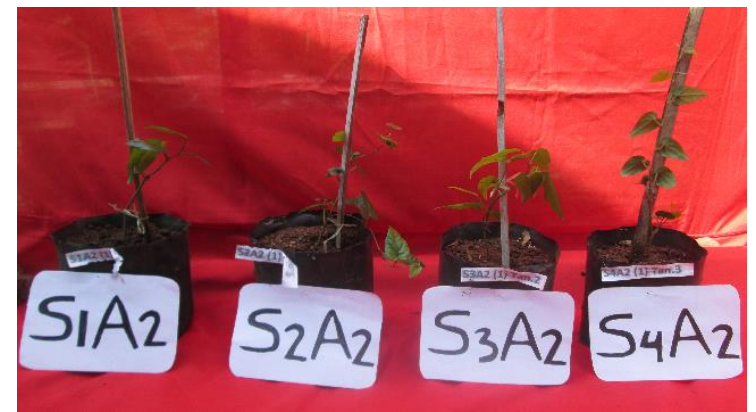

Figure 2. Long pepper plant performance three weeks after planting (WAP) with different growing media compositions. 
In the planting medium added with manure, the plant height increased by $6.18 \mathrm{~cm} / 2$ weeks (Figures 1 and 2). Meanwhile, for soil growing media alone, soil added with sand and soil added with rice husk charcoal each increased plant height by $2.72,3.22$, and $5.5 \mathrm{~cm} / 2$ weeks (Table $1)$. The increase in the number of leaves by 10.60 / 2 weeks from the plants planted on the soil is growing medium added with manure. The increase in the number of leaves is 1.5 times that of those planted in soil growing media alone (Table 1). In addition to plant height and number of leaves, the length of the roots in the soil planting medium added with cow manure showed the best results of $21.75 \mathrm{~cm}$ where the root length ranged from 1.07-1.70 times the length of the roots planted in soil, soil to which sand and soil added with rice husk charcoal.

Plants grown on media added with cow manure had a shoot and fresh root weights of $21.81 \mathrm{~g}$ and $15.13 \mathrm{~g}$, respectively, or ranged from 1.2-1.6 and 1.3-1.5 times that of planted in other media. However, there was no significant difference between the fresh root weight of the soil growing medium and the soil added with sand (Table 2).

The application of cow manure to the planting medium resulted in better plant performance and biomass than other growing media (Tables 1 and 2). All planting media have added the recommended amount of inorganic fertilizers. However, cow manure was able to increase nutrients more than sand or rice husks into the soil (Table 3). Besides, manure provides benefits to plants from its nutritional content and its effect on improving soil physical and biological properties.

The response of plants due to cow manure's addition to the planting medium resulted in the tops of the plants growing at dawn and falling. This is related to the water content of plants given cow manure, which is higher when compared to other growing media (Table 2); besides, it also results in limited root growth in polybags that cannot support many leaves. According to Zahreddine et al. (2004), plants planted in polybags can experience root circles caused by limited plant root growth space.

The addition of $1 / 4$ volume of sand and rice husks to the planting medium increased the growth of plant height, several leaves, and root length of herbal chillies. However, the variables' average value tended to be lower compared to those planted in soil media with added cow manure. This is because the nutrients in sand and rice husks have not been able to meet the herbal chilli plants' nutrient needs to support their growth. The addition of sand or rice husks to the media initially intended to increase better porosity and provide a lighter planting medium than clay soil, but what happened resulted in a lot of water loss from the soil so that sand or rice husks retained less water than clay soil. Mathers et al. (2007) stated that it required more water availability on a large substrate porosity to maintain moisture for plant growth.

\section{CONCLUSION}

In summary, the combination of soil and manure with $3: 1(\mathrm{v} / \mathrm{v})$ composition shows the best growing medium for the growth of long pepper (Piper retrofractum Vahl.). They indicated by producing the highest plant height, the number of leaves, root length, root and shoot fresh weight, and root and shoot dry weight at 14 weeks after planting (WAP). The use of the planting medium in soil alone causes the lowest growth and production of chili plants.

\section{ACKNOWLEDGEMENT}

This research was funded by the 2019 PNBP of Bengkulu University (UNIB) No. 2139/UN30.15/LT/2019.

\section{REFERENCE}

Badan Pengawasan Obat dan Makanan (BPOM). (2010) Acuan Sediaan Herbal. Vol. 5. Jakarta. $132 \mathrm{pp}$

Chaveerach, A., P., Mokkamul, R., Sudmoon, and Tanee, T. (2006) Ethnobotany of the genus Piper (Piperaceae) in Thailand, Ethnobotany Research \& Applications, 4, 223-231.

Evizal, R. (2013) Tanaman Rempah dan Fitofarmaka. Fakultas Pertanian Unila, Bandar Lampung.

Jamal, Y., Irawati, P., Fathoni, A., Agusta, A. (2013) Chemical constituents and antibacterial effect of essential oil of 
javaness pepper leaves (Piper retrofractum Vahl.), Media Litbangkes, 23(2), 65-72.

Kartasapoetra, G. (2004) Budidaya Tanaman Berkhasiat Obat. PT. Rineka Cipta, Jakarta. Page 50-51

Kim, K.J., Lee, M.S., Jo, K., Hwang, J..K. (2011) Piperidine alkaloids from Piper retrofractum Vahl. protect against high-fat diet-induced obesity by regulating lipid metabolism and activating AMP-activated protein kinase, Biochem. Biophys. Res. Commun., 411(1), 219-225.

Mathers, H.M., Lowe, S.B., Scagel, C., Struve, D.K., Case, L.T. (2007) Abiotic factors influencing root growth of woody nursery plants in containers, Reviews, Hort.Technology, 17, 151-162.

Mathew, S.P., Mohandas, S., Nair, G.M. (2004) Piper sarmentosum Roxb. - An addition to the flora of Andaman Islands, Current Science, 87, 141-142.

Melati, M., and Soleh, I. (2012) Pertumbuhan cabe jawa (Piper retrofractum Vahl.) perdu dengan berbagai teknik pemupukan, Jurnal Agrivigor, 11(2), 195-201.

Nurkhasanah, N., Wicaksono, K.P., Widaryanto, E. (2013) Studi pemberian air dan tingkat naungan terhadap pertumbuhan bibit tanaman cabe jamu (Piper retrofractum Vah.)., Jurnal Produksi Tanaman, 1(4), 34-41.

Ruhnayat, A., Muljati, R.S., and Haryudin, W. (2011) Respon tanaman cabe jawa produktif terhadap pemupukan di
Sumenep Madura, Bul. Littro., 22(2), 136146.

Santosa, E. (1993) Pengaruh pupuk buatan NPK $M g$ dan pupuk kandang terhadap pertumbuhan bibit cabe Jawa (Piper retrofractum Vahl.), Skripsi, Jurusan Budidaya Pertanian, Institut Pertanian, Bogor, Bogor: Jawa Barat.

Subramaniam, V., Adenan, M.I., Ahmad, A.R., Sahdan, R. (2003) Natural antioxidants: Piper sarmentosum (kadok) and Morinda elliptica (mengkudu), Mal J Nutr, 9, 4151.

Sulkani. (2013) Budidaya Cabe Jamu. Diambil dari www.ditjenbun.deptan.go.id/tanregar/ berita-207-budidaya-cabe-jamu.html.

Vasavirama, K.and Upender, M. (2014) Piperine: A Valuable Alkaloid from Piper Species, International Journal of Pharmacy and Pharmaceutical Sciences, 6(4), 34-38.

Vinay, S., Renuka, K., Palak, V., Harisha, C.R., and Prajapati (2012) Pharmacognostical and phytochemical study of Piper Longum L. and Piper retrofractum Vahl., Journal of Pharmaceutical and Scientific Innovation, 1(1), 62-66.

Zahreddine, H.G., Struve, D.K., Quigley, M. (2004) Growing Pinus nigra seedlings in Spinout-treated containers reduces root malformation and increases regrowh potential, J. Environ. Hort., 22, 176-182. 